\title{
Metrosexual Lifestyle and Interpersonal Relationships
}

\author{
Achmad Wildan Kurniawan, Silvi Sucira Listian, Zikri Fachrul Nurhadi, and Heri Hendrawan \\ Department of Communication Science \\ University of Garut \\ Garut, Indonesia \\ zikri_fn@uniga.ac.id
}

\begin{abstract}
The purpose of this study is to discover and explain the motives, meanings, self-concept and interpersonal relationships of men undergoing sexual metro lifestyles. The approach of this research is qualitative approach, with a phenomenological method and constructivism paradigms. Data collection techniques through in-depth interviews, participant observation, and literature review. Informants who studied a number of eight people by purposive sampling. The results showed that the motive for men undergoing a metrosexual lifestyle of career demands, interest in modern lifestyles, and association. While in order to motive is the times, look more interesting. In this case metro sexual men interpreted that metrosexuals are very concerned about appearance to look more confident and make the body more healthy and clean. A man's self-concept is seen from the psychological perspective of self, the physical perception of the self, and the social perception of the self that produces positive and negative views. On the other hand in running their interpersonal relationship is not a self-limiting figure, but indirectly they tend to perform the process of selection that is considered equivalent as having the same lifestyle so that the communication is effective. Then emerging models of interpersonal relationships between them, where they play their role in accordance with their environment.
\end{abstract}

Keywords-lifestyles, metrosexual, interpersonal relationships, phenomenology

\section{INTRODUCTION}

Appearance is a necessity in everyday life. The more life necessities, there is a demand for lifestyle improvement. As a result, it requires everyone to always up to date. Relating to lifestyle, then physical appearance becomes a very important thing in the modern era. People assume physical appearance will show their identity, especially in the social level of a person (Binus.ac.id, 2015). Where a person who has a neat appearance, and harmonious is a person who has a good social environment, as well as good self-ability. Conversely, if a person does not have an attractive physical appearance, harmonious will be considered someone who has inadequate capability. Although physical appearance is so important among people but only women are very concerned with physical appearance at first, while men are not too concerned about appearance. However, over time, so many changes that occur so that men increasingly concerned with appearance and body care. Nielsen mentioned that men who tend not to follow fashion trends are only $19 \%$ while $56 \%$ agree that wearing attractive clothing can increase confidence, this figure is only slightly lower than women (Binus.ac.id, 2015). The survey shows that nowadays men increasingly care and consider physical appearance is a very important thing and must be considered. Especially for men who live in metropolitan cities, where appearance becomes a very important element, not only as a supportive sense of self-esteem and self-confidence, but as a support and demands in the world of work. As reported by independent.co.uk Friday (2/5/2014) study from consulting agency Brain \& Co mentions globally, $40 \%$ of luxury goods sales are sales of male products and the number continues to grow (Liputan6, 2014 ). They are not the old masculine and muscular type of man, but woman-oriented man in other words, girly man. Not that they switch sexual orientation or lose their masculinity (Unair.ac.id, 2008). But instead they are men with more income that type of very concerned about themselves ranging from fashion, body care, maintaining a healthier lifestyle and no matter how much money it releases. This phenomenon, becomes buzzword around the world that these men are a term of metrosexual. The metrosexual lifestyle is increasingly becoming a trend phenomenon, along with the development of fashion, initially this trend only belongs to the top like celebrities, male models and young executives but now metrosexual behavior continues to penetrate into all elements and layers of society. The results of a metrosexual male survey conducted by MarkPlus \& Co in collaboration with EuroRSCG AdWork seen in table 1, that is:

TABLE I. Result of Metrosexual Male Survey

\begin{tabular}{|l|l|}
\hline \multicolumn{1}{|c|}{ Country } & \multicolumn{1}{|c|}{ Percentage of Population } \\
\hline Amerika & $20 \%$ \\
Inggris & $20 \%$ \\
Indonesia : & $15,7 \%$ \\
Jakarta & $(40,3 \%)$ \\
Bogor & $(10,1 \%)$ \\
Tangerang & $(14,5 \%)$ \\
Bekasi & $(15,9 \%)$ \\
Depok & $(16,2 \%)$ \\
\hline
\end{tabular}

Source: Kartajaya, 2006

According to table 1, the number of metrosexual men in the United States and Britain accounted for $20 \%$ of the total adult male population. While in Indonesia, based on research conducted from MarkPlus \& $\mathrm{Co}$ in collaboration with EuroRSCG AdWork in November-December 2003 this research involving about 400 adult men. To capture the affluent people in Jakarta, in this research selected respondents who come from social class $\mathrm{A}++$ who spent more than Rp. 5 million per month Metrosexual men had reached $15.7 \%$ of the male population in Jakarta (Jakarta, Tangerang, Bogor, Bekasi, Depok), and showed an increasing trend. In Indonesia in general the survey concluded that metrosexual men have grown even if compared 
to total men, the numbers are not significant. They have the characteristic of appreciating performances, adhering to gender equality, socializing, liberalism, narcissistic and self-worshiping (Kartajaya, 2006). The phenomenon of metrosexual men is a man who generally lives in big cities, has a lot of money, with a royal and hedonic urban lifestyle. It was done not just for shopping, but more for personal satisfaction (Kartajaya, 2004). A global market research firm, Mintel said total sales of male care products rose $3.6 \%$, as seen in table 2 .

TABle II. Men Who Do Personal CARE

\begin{tabular}{|l|l|}
\hline \multicolumn{1}{|c|}{ Personal Care Products } & Population Presentation \\
\hline Face moisturizer & $42 \%$ \\
Face cleanser & $22 \%$ \\
Lip Balm & $23 \%$ \\
Tissue Face & $16 \%$ \\
Eye Cream & $6 \%$ \\
Anti Aging & $8 \%$ \\
\hline
\end{tabular}

\section{Source: Mail, 2013}

According to table 2, men are increasingly aware of their personal care, corroborated by surveys showing that $42 \%$ of men use facial moisturizing products, and, as many as $22 \%$ of men use facial cleansing products. Not only the two cosmetics, lip balm also used $23 \%$ of men. While $16 \%$ of men use facial tissue. Then, as much as $6 \%$ of men use eye cream, as well as $8 \%$ of men using anti-aging products (Daily Mail, 2013). The metrosexual concept then leads to the lifestyle of modern urban men who earn more and are very concerned about his appearance and self-image. This lifestyle is closely related to consumerism, capitalism and even with the behavior of narcissism (Handoko, 2004). Metrosexual men pay more attention to appearance, they tend to have fashion sensibilities and choose quality or branded clothing, and have grooming habits or habits that were commonly associated with women (WIKIPEDIA, 2016). In this metrosexual lifestyle is also associated with the theory of self-concept, which defines that with the existence of self-concept, individuals view or assess themselves will be evident from all his behavior, in other words a person's behavior will be in accordance with the way the individual views and assess themselves (Rakhmat, 2008). This metrosexual lifestyle phenomenon arises because of the increasing number of women who work, the presence of career women in the workplace that previously dominated by men demanding men to take care of themselves and keep up appearances. The phenomenon of metrosexual men has been described earlier, making researchers interested in studying the lifestyle of metrosexual and interpersonal relationships. As for the question of this research is how motive, meaning, self concept and interpersonal relationship of men who choose metrosexual lifestyle. Based on previous exposure, the researchers are interested to conduct a communication research entitled: Lifestyle Metroseksual and Interpersonal Relationships.

\section{RESEARCH METHOD}

In this section, researchers will describe the results of research and discussion related to the motives, meanings, selfconcept and interpersonal relationship of men who choose a metrosexual lifestyle.

\section{RESULT AND DISCUSSION}

Based on the results of interviews conducted, researchers get the following results:

\section{A. Motives of Men Who Choose to Run a Metrosexual}

Metrosexual men pay more attention to appearance, who tend to have fashion sense and choose quality or branded clothing, and have grooming habits. The motives underlying men choose to run the metrosexual lifestyle shown in table 3 as follows:

TABLE III. Motives of Men Who Choose to Run a MetroseXual LIFESTYLE

\begin{tabular}{|l|l|}
\hline \multicolumn{1}{|c|}{ Motive Explanation } & Category \\
\hline $\begin{array}{l}\text { Motive Demands. Career demands to be } \\
\text { more attention in front of others }\end{array}$ & \multirow{2}{*}{ Because motive } \\
\cline { 1 - 1 } others
\end{tabular}

Source: Model Categorization of Interview Results, 2017

Based on the interviews, there are two motives, a motive for, which means that something is a goal that is described as a purpose, plan, hope, interest-oriented future. The future here is where informants who choose to run the metrosexual lifestyle to meet their inner needs or fulfill the need for the future. The results of the categorization of the motive for, in the form: needs, the development of the times, improve social status. While the motive because, appearing as a result of metrosexual men who look back or experience and knowledge for choosing to run the lifestyle metroseksual, such as the result of motive categorization because of the demands, interests and association.

\section{B. Metrosexual Meaning to Metrosexual Men}

A meaning arises from one's thinking when looking at a phenomenon. Of course, when talking about the meaning of different results with each other, even if there is a little equality and there is still a difference of one two words made by each person. The results of interviews to informants can represent the meaning of men who choose to run the metrosexual lifestyle seen in table 4, namely:

TABLE IV. The MeAning of Men Who Choose RunNing the METROSEXUAL LIFESTYLE

Knowledge in appearance

Look more comfortable, fragrant and more neat

Keeping the body clean and more confident

Attract other people's attention, charismatic appearance and more fit body It has a high taste and up to date

As a Self Identity (Different from others)

More concerned with the appearance of yourself to be more fashionable

Means of information about fashion brand to overcome the times

Maintain a healthier body

Source: Model Categorization of Interview Results, 2017 
In general, according to the results of interviews conducted, that the informant has a special meaning of knowledge in the skills that can be applied or adjust the appearance in certain situations, perfect appearance such as more fragrant and neat will make it more comfortable to show off in front of others, in addition to attract the undeniable attention can get the praise of many people for the appearance worn. Someone with a metrosexual lifestyle is well known as a figure who keeps clean, caring for the body more healthy and attention to appearance to look fashionable make someone more confident in living their daily life, it's no wonder now many men are handsome, charismatic and have a fit body because not only women who are good at preening, but many men are trying to pay attention to his appearance as perfect as possible, supported by market products that are growing and increasing in Indonesia. Another meaning of metrosexual is as a means of information, has a high lifestyle taste that tends to follow the development of the era and more up to date on local and international fashion, or more to the hypbeast ie a fashion enthusiast, either branded goods, technology or booming fashion style

\section{Self-concept Men Who Implement the Metrosexual Lifestyle}

The self-concept analyzed is how to understand the attitude or feelings of a metrosexual man, the expectations of a metrosexual man and the judgment of a metrosexual man while undergoing a metrosexual lifestyle. Any perception of the self is either psychological, social and physical or perceptions of others will result in positive and negative perceptions. Negative views and attitudes toward the quality of abilities have resulted in individuals viewing the entire task as a difficult thing to solve. On the other hand, a positive view of the quality of abilities that leads to individual individuals perceives all tasks as an easy thing to accomplish. Here in table 5, is the selfconcept of men who choose to run the metrosexual lifestyle, namely:

TABLE V. SELF-CONCEPT MEN Who IMPLEMENT The METROSEXUAL LIFESTYLE

\begin{tabular}{|c|c|}
\hline $\begin{array}{c}\text { Perspectives of Self } \\
\text { Concept }\end{array}$ & Explanation \\
\hline $\begin{array}{l}\text { A psychological } \\
\text { perspective on self }\end{array}$ & $\begin{array}{l}\text { - There is satisfaction and pleasure } \\
\text { in oneself } \\
\text { - Has the nature of narcissism and } \\
\text { confidence }\end{array}$ \\
\hline $\begin{array}{l}\text { A social perspective on } \\
\text { self }\end{array}$ & $\begin{array}{l}\text { - Metrosexual still underestimated } \\
\text { - There is praise for metrosexual } \\
\text { men } \\
\text { - Become another community } \\
\text { trendsetter }\end{array}$ \\
\hline $\begin{array}{l}\text { Physical perspective } \\
\text { about self }\end{array}$ & $\begin{array}{l}\text { - Become someone who is more } \\
\text { liked by others } \\
\text { - There are changes that pay more } \\
\text { attention to the appearance of } \\
\text { both hygiene and body health }\end{array}$ \\
\hline
\end{tabular}

The psychological perception of the self is a self-knowledge picture that includes what we know about ourselves, including in this case such as gender, ethnicity, occupation, age group, ethnic group or certain groups. Knowledge of self can be the nature or personality it has (Rakhmat, 2008). Based on the concept of self-concept that includes the psychological perception of the metrosexual self-man identity, attitude or personality and feelings. In general, all informants have knowledge about themselves, which perceives itself as a positive value, in which a man who chooses to run a metrosexual lifestyle feels so happy, relaxed and enjoys his lifestyle that is applied in his daily life. In addition, with metrosexual lifestyle makes the informants assess himself as a metrosexual man who seemed casual, simple, more confident and interesting. On the other hand, there are some informants who judge themselves negatively, ie for those with a metrosexual lifestyle as a man who is wasteful, hedonic and has a selfish attitude. They become a wasteful and hedonic person because they meet his needs as a metrosexual man in order to maintain his appearance in front of others. The social perception of the self is the social condition and the perception of others towards a person and the expression of an attitude, the opinion can vary both in terms of intensity and stability. Neuman states that opinion is the level of consent of a particular population (West \& Turner, 2007: 122), so there is a sense of pride and satisfaction in itself to be a figure that is noticed for men who undergo a metrosexual lifestyle.

\section{The Interpersonal Relationship of Men Living the Metrosexual Lifestyle}

Interpersonal Relationships analyzed is how every metrosexual man undergo a relationship not just want to build relationships or relationships only. When examined, interpersonal relationships are not a passive relationship, but a purposeful activity. Effective communication is characterized by good interpersonal relationships. How every metrosexual man communicates, they not only convey the message content, but also determine the level or motivation in their interpersonal relations (Rakhmat, 2012). The following table 6 deals with the interpersonal relationships of men who choose to run the metrosexual lifestyle, namely:

TABLE VI. THE INTERPERSONAL RELATIONSHIP OF MEN LIVING THE METROSEXUAL LIFESTYLE

Interpersonal Relationship
Before building interpersonal relationship with someone, they seem to
improve the appearance, there are also directly socialize with others, on
the other hand, they become themselves, there are also those with a cool
personality.
Their motivation to run interpersonal relationships is generally to add
relationships, add insight, increase networking, add benefits, be a
trendsetter and gain feedback from others.
Selective in choosing who will be personally connected
Adjusting its role according to its environment in order to be accepted
by others
Entering the environment voluntarily as long as the environment is
satisfactory and mutually beneficial.

Source: Model Categorization of Interview Results, 2017

Based on the concept, in addition to maintaining the appearance that informants also pay attention to how to communicate, what is discussed, and how to look at something, such as the statement of one informant, that a metrosexual can 
be seen from the way in communicating directed, mutual respect, and not excessively joke. As with language functions, one of them is to enable us to be more organized, and to understand each other about ourselves. It is impossible for a person to use words at random but to arrange them based on certain rules (Mulyana, 2007). Metrosexual lifestyle is not only always associated with the face and body are maintained, there are other aspects that are more important than just the physical appearance of the aspects of communication both in what way is spoken and the use of language used as a form of verbal communication. It is useful to create a good image and add value to those who live a metrosexual lifestyle. Basically, the pattern of interpersonal relationships from introductions to togetherness, separation, reconciliation, toward togetherness and so on. At each stage the interpersonal relationships play a different role. At the introductory stage, communication serves as a means to get to know each other while at the stage of communications together to maintain the role of interpersonal relationships remain harmonious (Suranto, 2011). The relationship also symbolizes the extent to which their openness to others. Growing and possessing beliefs are increasingly affecting the openness that is entwined. Things like this will create good interpersonal relationships (Suranto, 2013). The greater the closeness of a relationship, will affect its openness. On the other hand, metrosexuals will limit information about things that are very personal to avoid any conflict in an interpersonal relationship, the extent of openness that exists, still in reasonable level.

\section{CONCLUSION}

Based on the results of previous research, there are some conclusions on metrosexual lifestyle research and interpersonal relationships, namely:

The phenomenon of metrosexual lifestyle and interpersonal relationships have motives that fall into two categories, namely, the motive because, that the core motive of the metrosexual lifestyle is the lifestyle needed for daily life so that the appearance is more manicured so look neat, attractive appearance, awake, have a healthy body, and fit. In addition, the metrosexual lifestyle can apply its appearance under certain conditions. While metrosexual meaning for metrosexual man is a self identity or social status in which a person with a branded outfit, lifestyle that impressed hedonis, perfect appearance will have a high social status look charismatic, authoritative, and have a different identity with men generally. It also affects the self-concept of metrosexual men about the psychological perception of self, the social perception of self and the physical perception of the self can be concluded that every informant is able to evaluate himself so that they are aware of the actions that have been done, that criticism of self often serves as a regulator or signs in acting and behaving to be able to adapt well. While interpersonal relationships metrosexual men that is, there is a model of interpersonal relationships conducted by the informant that is a model of social exchange seen between behavior with the environment there is a relationship that affect each other. This model of social exchange, will value a relationship as an important bond, so that the relationship also symbolizes the extent of their openness to others, open themselves by expressing themselves openly and candidly.

\section{REFERENCES}

[1] Binus.ac.id. (2015, September 9). Accessed on 27 Februari 2017. Metrosexual behavior with interpersonal skill in men: http://psychology.binus.ac.id/2015/09/09/ Metrosexual behavior with interpersonal skill in men.

[2] Creswell, Jhon W. (2002). Research Design: Qualitative \& Quantitative Approaches. Jakarta: KIK Press.

[3] Daily Mail. (2013, Juli 18). Accessed on 28 Februari 2017, Rise in the metrosexual: Sales of men's beauty products soar $20 \%$ in five years: http://www.dailymail.co.uk/news/article-2367711/Rise-metrosexualSales-mens-beauty-products-soar-20-years.html.

[4] Handoko, T. Hani. (2004). Personnel and Human Resource Management. Yogyakarta: BPFE.

[5] Hidayat, Arie. (2012). Trends in Luxury Style and Color Hair, Java Posa, Edition 12 Juni 2012, https://www.jawapos.com.

[6] Kartajaya, Hermawan. (2004). Marketing In Venus. Jakarta: Gramedia Pustaka Utama.

[7] Kartajaya, Hermawan. (2006). Hermawan Kartajaya Series 9 Elements of Marketing. Bandung: Mizan Pustaka.

[8] Kartajaya, Hermawan. (2006). Marketing In Venus Playbook. Jakarta: Gramedia Pustaka Utama.

[9] Mulyana, Deddy. (2007). Qualitative Research Methodology, New Paradigm of Communication Science and Other Social Sciences. Bandung: PT. Remaja Rosdakarya.

[10] Nurhadi, Zikri Fachrul. (2017). Theory of Contemporary Communication. Depok: Kencana.

[11] Rakhmat, Jalaluddin. (2008). Communication Psychology. Bandung: Remaja Rosdakarya.

[12] Rakhmat, Jalaluddin. (2012). Communication Psychology. Edisi Revisi. Bandung: Remaja Rosdakarya.

[13] Sugiyono. (2010). Quantitative Research Methods, Qualitative, and R \& D. Bandung: Alfabeta.

[14] Suranto, A.W. (2011). Interpersonal Communication. Yogyakarta: Graha Ilmu.

[15] Suranto, A.W. (2013). Interpersonal Communication. Revised Edition. Yogyakarta: Graha Ilmu.

[16] Unair.ac.id. (2008, Desember 17). Accessed on 26 Februari 2017, Male Lifestyle Metrosexual in Magazines http://adln.lib.unair.ac.id/go.php?id=gdlhub-gdl-s1-2008-purnamawar9110\&PHPSESSID $=\mathrm{a} 8764 \mathrm{cbcbd} 82 \mathrm{e} 3 \mathrm{de} 543 \mathrm{ea} 5 \mathrm{dceb} 48224 \mathrm{~d}$.

[17] Wikipedia. (2016, Oktober 9). Diaskes pada 27 Februari 2017, Metroseksual: https://id.wikipedia.org/wiki/Metroseksual.

[18] Wes, Turner. (2007). Introduction to Communication Analysis and Applications. Jakarta: Salemba Humanika. 